\title{
Menuju Parlemen Bikameral (Studi Konstitusional Perubahan Ketiga UUD 1945) ${ }^{1}$
}

\author{
Dahlan Thaib
}

\begin{abstract}
The consequences of using these two chambers, it wipes out the district regulation/district representative and the composition of People's Consultative Assembly, so that there is no special position for the Indonesian National Armed Forces and The Indonesian Police Force at The People's Consultative Assembly. The Group Delegate and the representative of The Indonesian National Armed Forces and The Indonesian Police Force at The People's Consultative Assembly are deleted. It is taken because the apply of this people's representative system called bicameral as mentioned above namely Delegate and The Indonesian National Armed Forces/ The Indonesian Police Force can be manifestated through both Group two Legislative Board.
\end{abstract}

\section{Pendahuluan}

Gema reformasi yang bergaung beberapa waktu yang lalu ternyata telah menggetarkan hampir semua sendi-sendi kehidupan berbangsa dan bernegara. Semenjak itu sampai dewasa ini, diskursus tentang perlunya penyesuaian-penyesuaian terhadap tuntutan perubahan dalam dinamika kehidupan politik ketatanegaraan Indonesia menjadi berlangsung dengan marak tanpa henti-hentinya, baik itu dilakukan oleh para akademisi, politisi, insan pers, maupun LSM. Dari sudut pandang Hukum Tata Negara fenomena ini tentu saja sangat penting dan positif dalam rangka membentuk atau mendesain demokrasi yang berorientasi pada keadilan, supremasi hukum, civil society, checks and balances yang menabukan dominasi kekuasaan seperti presiden, akuntabilitas kekuasaan dan pluralisme atau kemajemukan dalam konteks Negara Kesatuan Republik Indonesia (NKRI).

Gerakan reformasi dewasa ini ternyata telah menyentuh aspek fundamental kehidupan berbangsa dan bernegara, yakni

${ }^{1}$ Pernah disampaikan dalam Pidato Pengukuhan dalam jabatan Guru Besar Madya dalam Hukum Tata Negara Fakultas Hukum Universitas islam Indonesiayang disampaikan di depan Sidang senat Terbuka Universitas Islam Indonesia (UII) Yogyakarta pada tanggal 4 Mei 2002. 
dengan diubahnya Undang-Undang Dasar 1945 oleh Majelis Pemusyawaratan Rakyat (MPR) melalui perubahan pertama dalam Sidang Umum MPR 1999, perubahan kedua dalam Sidang Tahunan 2000 dan perubahan ketiga dalam Sidang Tahunan bulan November 2001. UUD 1945 yang dirancang dan dirumuskan oleh tokoh-tokoh bangsa pendiri negara lebih setengah abad yang lalu ternyata dalam perkembangan berikutnya menuntut adanya perubahan-perubahan sesuai dengan kebutuhan jaman dan dinamika masyarakat.

Tuntutan terhadap perubahan konstitusi atau Undang-Undang Dasar dikarenakan tidak ada satu sistem ketatanegaraan yang digambarkan dalam konstitusi atau UndangUndang Dasar sudah sempurna pada saat dilahirkan, karena konstitusi adalah produk jamannya. Dapat terjadi bahwa dalam perkembangan berikutnya menjadi tidak serasi dengan kebutuhan jaman dan dinamika masyarakat sebagaimana dikemukakan di atas. Karena itu adakalanya suatu konstitusi atau Undang-Undang Dasar diubah atau diganti dengan Konstitusi atau UndangUndang Dasar yang paru. UUD 1945 adalah produk masanya, sebagai hasil pemikiran para negarawan penyusunnya pada waktu itu. Dalam kurun waktu perkembangannya mungkin saja terasa sesuatuyang perludi diıbah dalam UUD 1945 sebagai perangkat Sistem Ketatanegaraan Indonesia.

Permasalahan yang mencuat adalah bagaimanakah cara atau sistem mengubahnya. Gagasan perubahan atau amandemen UUD
1945 hingga dewasa ini ternyata telah melahirkan kutub-kutub perbedaan antara yang pro dan kontra. Lepas dari pro dan kontra perubahan atau amandemen UUD 1945, amandemen harus terus dilakukan, mengingat amandemen adalah tuntutan masyarakat yang ingin reformasi. Dari kacamata pandang Hukum Tata Negara amandemen atau perubahan UUD 1945 merupakan amanat TAP MPR No. XI Tahun 2001 yang harus diselesaikan oleh Badan Pekerja MPR.

Dalam teori ketatanegaraan terdapat beberapa macam prosedur dalam mengubah Undang-Undang Dasar, yaitu:'2 (1)Perubahan konstitusi yang dilakukan oleh pemegang kekuasaan legislatif, akan tetapi menurut pembatasan-pembatasan tertentu; (2) Perubahan konstitusi yang dilakukan dalam suatu konvensi atau dilakukan oleh suatu lembaga negara khusus yang dibentuk hanya untuk keperluan perubahan; (3) Perubahan konstitusi yang dilakukan oleh rakyat melalui suatu referendum.

Selain cara atau prosedur perubahan konstitusi sebagai dikemukakan diatas, ada masalah lain yang juga perlu dikemukakan dalam rangka mengubah konstitusi atau Undang-Undang Dasar, yaitu "sistem" yang digunakan. Pada dasarnya ada dua sistem yang digunakan, yaitu: ${ }^{3}$ (1) Apabila suatu Undang-Undang Dasar diubah, maka yang akan berlaku adalah Undang-Undang Dasar atau konstitusi baru secara keseluruhan; (2) Apabila suatu Undang-Undang diubah, maka Undang-Undang Dasar atau konstitusi yang

${ }^{2}$ C.F. Strong, Modern Political Constitution (London: ELBS Edition First Published, Sidgwick \& Jackson Limited, 1966), hlm. 146-148.

${ }^{3}$ Sri Soemanti M, Prosedur dan Sistem Perubahan Konstitusi (Bandung: Penerbit Alumni, 1979), him. 71. 
"asli" tetap berlaku. Perubahan terhadap konstitusi tersebut merupakan amandemen dari konstitusi yang asli tadi. Dengan perkataan lain amandemen tersebut merupakan atau menjadi bagian dari konstitusinya.

Kedua sistem itulah yang dianut oleh negara-negara modern dewasa ini. Amerika Serikat menganut sistem kedua, Konstifusi Amerika Serikat yang sudah ada sejak tahun 1787 sampai dewasa ini masih dipertahankan. Oleh karena itu, sebenarnya dalam rangka perubahan UUD 1945 dapat mencontoh model seperti negara Amerika Serikat, karena di antara UUD 1945 dan Konstitusi Amerika Serikat ada persamaannya.

\section{Perubahan Ke Arah Sistem Bikameral}

Setelah tiga dasawarsa bangsa ini terpasung, maka tidak dapat tidak reformasi UUD 1945 harus merupakan conditio sine quo non untuk tegaknya demokrasi, rule of law, pengendalian kekuasaan dan memungkinkan warga negara secara maksimal mempergunakan kebebasan individual dan hak politik partisipatorisnya.

Perubahan UUD' 1945 merupakan hal yang wajar dan bisa terjadi, karena memang diatur dalam Pasal 37 UUD 1945. Apabila dapat dilakukan lembaga yang berwenang yakni Majelis Permusyawaratan Rakyat (MPR) mempunyai keinginan politik untuk perubahan itu, sepanjang perubahan itu tidak mengubah Pembukaan UUD 1945, karena di dalam Pembukaan UUD 1945 terdapat Rumusan Dasar Negara, Berkat Rahmat Allah yang Maha Kuasa, juga merupakan bagian yang tidak terpisahkan dari Proklamasi. Selain mempertahankan Pembukaan UUD 1945, maka pada proses awal, sebelas fraksi di MPR telah menyepakati pula bahwa dalam kerangka amandemen UUD 1945 juga tetap mempertahankan: (1) Bentuk negara kesatuan Republik Indonesia; (2) Sistem Pemerintahan Presidensil, dan (3) Hal-hal normatif di dalam Penjelasan akan dipindahkan ke dalam pasalpasal UUD.

Sebagaimana telah disampaikan di atas, maka dalam suasana reformasi sekarang, MPR berdasarkan kewenangan yang diberikan oleh Pasal 37UUD 1945, telah melakukan perubahan pertama, perubahan kedua dan perubahan ketiga terhadap UUD 1945.

Pada Sidang Tahunan MPR bulan November tahun 2001, MPR setelah mempelajari, menelaah, dan mempertimbangkan dengan sungguh-sungguh hal-hal yang bersifat mendasar yang dihadapi oleh rakyat, bangsa dan negara serta dengan menggunakan kewenangannya berdasarkan Pasal 37 UUD 1945, MPR telah melakukan perubahan ketiga UUD $1945 .^{4}$

Salah satu materi muatan dalam rangka perubahan ketiga UUD 1945 adalah mengenai posisi MPR tidak lagi sebagai lembaga tertinggi negara dalam Sistem Ketatanegaraan Indonesia pasca Pemilihan Umum 2004. Berdasarkan perubahan tersebut, maka pada masa yang akan datang lembaga parlemen dikembangkan menjadi dua kamar (bikameral). Kedua kamar parlemen itu akan dinamakan DPR (Dewan Perwakilan Rakyat) dan DPD (Dewan Perwakilan Daerah) dengan tetap mempertahankan MPR sebagai nama forum

\footnotetext{
‘Perubahan Ketiga Undang-Undang Dasar Negara Republik Indonesia Tahun 1945
} 
persidangan bersama antara kedua kamar parlemen tersebut.

Perubahan ketiga UUD 1945, akan lebih mempertegas dianutnya sistem pemerintahan presidensiil, karena dihapusnya konsep lembaga tertinggi negara MPR tempat Presiden harus bertanggung jawab sebagaimana lazim ditemui dalam sistem pemerintahan parlementer. Di samping itu, perubahan ini akan pula mempertegas dianutnya sistem pemisahan kekuasaan dan prinsip "checks and balances" di antara lembaga-lembaga tinggi negara.

Permasalahannya apakah sistem bikameral akan cocok atau sesuai dalam praktek ketatanegaraan Indonesia di masa yang akan datang, kendatipun sistem bikameral kini merupakan materi muatan dari konstitusi baru Indonesia hasil perubahan ketiga UUD 1945. Sebagaimana diketahui, Parlemen mempunyai dua macam sistem yaitu unikameral dan bikameral. Unikameral berarti Dewan Perwakilan Rakyat (DPR) tidak memakai kamar-kamar, namun menggunakan komisi. Sementara dalam sistem bikameral, parlemen memiliki dua kamar, yaitu DPR dan Senat. DPR sering disebut House of Representative atau Majelis Rendah (Lower House), sedangkan Senat disebut juga Majelis Tinggi (Upper House). Lazimnya, sistem bikameral dan unikameral mengacu pada DPR atau Parlemen, dan tidak mengacu pada Majelis Permusyawaratan Rakyat (MPR). Dalam sistem bikameral, DPR adalah salah satu kamar dalam parlemen. Sedangkan dalam sistem unikameral, DPR itu sendiri adalah parlemen.

Sistem bikameral biasanya dianut oleh negara-negarayang berbentuk federasi seperti Amerika Serikat. Dengan sistem ini negaranegara bagian dalam federasi tersebut terwakili dalam parlemen melalui senat, sementara kamar lainnya (House of Representative) adalah perwakilan rakyat secara keseluruhan. Bila kedua kamar tersebut berkumpul barulah disebut kongres. Namun demikian, ada sejumlah negara berbentuk kesatuan seperti Inggris dan Belanda yang juga menganut sistem Bikameral: Di Belanda misalnya, satu kamar (Majelis Tinggi) merupakan perwakilan dari kaum bangsawan, sementara kamar yang lain (Majelis rendah) adalah perwakilan penduduk secara keseluruhan.

Dalam praktek ketatanegaraan, baik legislatif bikameral maupuñ legislatif unikameral masing-masing mempunyai kelebihan dan keuntungan sebagaimana tergambar di bawah ini. Kelebihan/keuntungan dalam sistem legislatif bikameral adalah kemampuan anggota untuk: (1) Secara resmi mewakili beragam pemilih (misalnya negara bagian, wilayah, etnik, atau golongan); (2) Memfasilitasi pendekatan yang bersifat musyawarah terhadap penyusunan perundangundangan; (3) Mencegah disyahkannya perundang-undangan yang cacat atau ceroboh; dan (4) Melakukan pengawasan atau pengendalian yang lebih baik atas lembaga eksekutif.

Beberapa keuntungan dalam sistem legislatif unikameral, meliputi: (1) Kemungkinan untuk dengan cepat meloloskan UndangUndang (karena hanya satu badan yang diperlukan untuk mengadopsi Rancangan Undang-Undang sehingga tidak perlu lagi menyesuaikan dengan usulan yang berbedabeda); (2) Tanggung jawab lebih besar (karena anggota legislatif tidak dapat menyalahkan majelis lainnya apabila suatu UndangUndang tidak lolos, atau bila kepentingan 
warga negara terabaikan); (3) Lebih sedikit anggota terpilih sehingga lebih mudah bagi masyarakat untuk memantau mereka; dan (4) Biaya lebih rendah bagi pemerintah dan pembayar pajak. ${ }^{5}$

Dalam konteks ketatanegaraan di Negara Kesatuan Republik Indonesia dewasa ini, berdasarkan UUD 1945 di tingkat pusat dikenal adanya dua badan perwakilan rakyat yakni MPR dan DPR. Namun demikian, tidaklan berarti sistem ketatanegaraan Indonesia dewasa ini menganut parlemen bikameral, karena MPR dan DPR mempunyal fungsi yang berbeda. Fungsi MPR antara lain adalah menetapkan Undang-Undang Dasar (UUD), dan Garis-Garis Besar Haluan Negara (GBHN) serta memilih-Presiden dan Wakil Presiden (Pasal 3 dan Pasal. 6 ayat 2 UUD 1945). Sementara fungsi DPR adalah menyusun Undang-Undang (UU); mengawasi pemerintah dan menetapkan Anggaran Pendapatan dan Belanja Negara (APBN) bersama Presiden. Karena itu dengan telah dilakukan perubahan ketiga UUD 1945 oleh MPR dalam Sidang Tahunan. MPR tahun 2001 yang telah lalu dan dihapusnya MPR sebagai lembaga maka dalam praktek Ketatanegraan indonesia yang akan datang badan legislatif akan terdapat dua lembaga, yaitu Dewan Perwakilan Rakyat (DPR) dan Dewan Perwakilan Daerah (DPD).

Dengan kata lain, yang disebut sebagai badan legislatif adalah suatu badan yang bersifat bikameral yang memiliki dua kamar, yaitu Dowan Perwakilan Rakyat (DPR) sebagal kamar yang satu, dan Dewan Perwakilan Daerah (DPD) sebagai kamar yang lain. Dua macam badan legislatif ini diperlukan untuk mengakomodasi kepentingan politik dan kepentingan daerah dalam sistem ketatanegaraan Indonesia yang akan datang.

Di dalam menjalankan fungsi dan wewenangnya, kedua badan legislatif itu bisa berjalan sendiri-sendiri, tetapi bisa juga bersidang bersama untuk .membahas persoalan yang dianggap penting. Persidangan bersama antara badan legislatif itulah yang disebut sebagai MPR. Dengan demikian, dengan dihapuskannya MPR sebagai lembaga, keberadaan MPR tetap diperlukan, yaitu sebagai forum bersama antara DPR dan DPD. Dengan kata lain, MPR sebagai forum, dan bukan sebagai lembaga. Karena sebagai forum, maka MPR tidak perlu lembaga, tetapi hanya merupakan sidang gabungan (join session) antara kedua lembaga legislatif. Adapun ketua sidang dalam sidang gabungan itu, dipilih berdasarkan kesepakatan anggota dari dua badan legistif tersebut. ${ }^{6}$

Dalam kaitannya dengan MPR pasca perubahan ketiga UUD 1945, maka memasuki Pemilihan Umum tahun 2004 yang akan datang Presiden dan Wakil Presiden terpilih dalam satu pasangan secara langsung oleh rakyat:" Terwujudnya gagasan pemilihan Presiden dan Wakil Presiden secara langsung oleh rakyat lewat perubahan ketiga UUD 1945 , tentunya akan menggeser kewenangan MPR

${ }^{5}$ National Democratic Intitute For International Affair(NDI), "Seri Penelitian Legislatif, Satu atau Dua Kamar?", tanpa tahun, him. 2-3.

${ }^{6}$ Tim Peneliti Kerja Sama Puslitbang Kemasyarakatan dan Kebudayaan-LIPI, Reposisi Lembaga Tinggi Negara, Jakarta, Maret 2001, hlm. 28

7 Pasal 6A Perubahan Ketiga UUD 1945 
dalam praktek ketatanegaraan mendatang.

MPR dalam praktek ketatanegaraan mendatang hanya berwenang mengubah dan menetapkan Undang-Undang Dasar ${ }^{8}$, karena Garis-Garis Besar Haluan Negara (GBHN) beralih menjadi kewenangan Presiden dan partai politik yang mendukungnya seperti tertuang dalam program-program partai. Itu merupakan konsekuensi logis pemilihan Presiden langsung oleh rakyat.

Ada beberapa alasan yang amat mendasar untuk melakukan pemilihan presiden secara langsung oleh rakyat. ${ }^{9}$ Pertama, Presiden yang terpilih melalui pemilihan langsung akan mendapat mandat dan dukungan yang lebih nyata dari rakyat sebagai wujud kontrak sosial antara pemilih dengan tokoh yang dipilih. Kemauan orang-orang yang memillh (volonte generale) akan menjadi pegangan bagi presiden dalam melaksanakan kekuasaannya. Kedua, pemilihan Presiden secara langsung oleh rakyat secara otomatis akan menghindari intrik-intrik politik dalam proses pemilihan dengan sistem perwakilan. Ketiga, pemilihan Presiden langsung akan memberi kesempatan luas kepada rakyat untuk menentukan pilihan secara langsung tanpa mewakilkan kepada orang lain. Kecenderungan dalam sistem perwakilan adalah terjadinya penyimpangan antara aspirasi rakyat dengan wakilnya. Ini makin diperparah atas dominannya pengaruh partai politik yang telah mengubah fungsi wakil rakyat menjadi wakil partai politik (political party representation). Keempat, pemilihan langsung dapat menciptakan perimbangan antara berbagai kekuatan dalam penyelenggaraan negara terutama dalam menciptakan mekanisme checks and balances antara presiden dengan lembaga perwakilan karena sama-sama dipilih rakyat. Dalam sistem ketatanegaraan Indonesia selama ini, MPR menjadi sumber kekuasaan dalam negara karena ada ketentuan lembaga ini adalah pemegang kedaulatan rakyat. Kekuasaan inilah yang dibagi-bagikan secara vertikal kepada lembaga-lembaga tinggi negara lain termasuk Presiden. Akibatnya, kelangsungan kedudukan Presiden amat tergantung kepada MPR. Sebelum dilakukan perubahan Undang-Undang Dasar yakni perubahan pertama, kedua dan ketiga UUD 1945 oleh MPR hasil Pemilu 1999, Negara Kesatuan Republik Indonesia (NKRI) menganut sistem Kabinet Presidensiil, sementara sistem pemerintahannya Parlementer. Disebut Kabinet Presidensill, karena Presiden adalah Kepala Pemerintahan dan menteri diangkat dan diberhentikan oleh Presiden. Disebut Pemerintahan Parlementer, karena Presiden dapat diberhentikan oleh MPR setiap saat. DPR dapat meminta MPR menyelenggarakan Sidang Istimewa (SI) MPR dengan persetujuan lebih dari setengah anggota MPR. Jjka lebih dari setengah anggota MPR menilai Presiden telah melanggar UUD 1945 atau GBHN, Presiden dapat diberhentikan sebelum masa jabatannya habis. Dibandingkan dengan Amerika Serikat (AS) yang menganut sistem presidensiil murni, Presiden tidak dapat diberhentikan di tengah masa jabatannya yang 4 tahun. Dia hanya dapat dihentikan dengan alasan moral, bukan politik.

${ }^{8}$ Pasal 3 Perubahan Ketiga UUD 1945.

${ }^{9}$ Harian Kompas, 24 September 2004. 
Dengan adanya pemilihan langsung oleh rakyat pasca Pemilu 2004 maka Presiden secara politik tidak akan bertanggung jawab. lagikepada MPR, melainkan akan bertanggung jawab langsung kepada rakyat yang memilih Presiden. Namun demikian tidaklah berarti presiden yang akan datang kekuasaannya tidak dibatasi. Kekuasaan Presiden dalam praktek ketatanegaraan harus tetap dibatasi dan salah satu fungsi konstitusi adalah pembatasan kekuasaan dalam negara. ${ }^{10}$ Sebagai sebuah negara modern, konstitusi indonesia dengan tegas menggariskan bahwa salah satu ciri dari Sistem Pemerintahan Indonesia adalah menganut asas negara hukum (rechtstaat) dan bukan negara kekuasaan (machtstaat). Menurut Friedman, negara hukum identik dengan rule of law. Istilah rechtstaat menurut Friedman mengandung arti pembatasan kekuasaan oleh hukum. ${ }^{1}$

Pasca Orde Baru, masalah klasik yang sama yang timbul pada era reformasi dewasa ini adalah masalah penegakan hukum di satu pihak dan pembatasan kekuasaan di pihak lain. Gema tuntutan penegakan supremasi hukum yang bergaung dalam percaturan poltik ketatanegaraan Indonesia dewasa ini tidak hanya sekedar dilatarbelakangi oleh sejarah ketatanegaraan Indonesia yang traumatis di kala hukum tidak berdaya berhadapan dengan kekuasaan, tetapi terlebih karena secara konstitusional prinsip negara hukum, bukan negara kekuasaan merupakan prinsip konstitusi yang harus ditegakkan."

Berangkat dari asumsi tersebut dan berdasarkan ketentuan konstitusi (UUD 1945) sebagaimana dikemukakan di atas berarti pemerintah mempunyai kekuasaan yang terbatas dan tidak dapat dibenarkan sewenang-wenang. Asas yang dianut tersebut haruslah tercermin dalam praktek penyelenggaraan ketatanegaraan Indonesia. Artinya dalam praktek ketatanegaraan Indonesia, hukum harus mengendalikan kekuasaan, bukan sebaliknya hukum dipecundangi oleh kekuasaan. Mengapa kekuasaan harus dibatasi, jawabnya adalah karena menurut Lord Acton, kekuasaan itu cenderung untuk disalahgunàkan, setiap bentuk kekuasaan cenderung memperbesar dan mempertahankan diri (power tends to corrupts, but absolute power corrupts absolutely). ${ }^{12}$ Maka di sinilah perlu peran hukum untuk membatasi kekuasaan dalam negara. ${ }^{13}$

Konstitusi Indonesia baru lewat perubahan ketiga UUD 1945 menegaskan bahwa "Presiden dan atau Wakil Presiden dapat diberhentikan dalam masa jabatannya oleh Majelis Permusyawaratan Rakyat atas usul Dewan Perwakilan Rakyat, baik apabila terbukti telah melakukan pelanggaran hukum berupa pengkhianatan terhadap negara, korupsi, penyuapan, tindakan pidana berat lainnya, atau perbuatan tercela maupun apabila terbukti

${ }^{10}$ K.C. Wheare, Modem Constitution (London: Oxford University Press, New York-Toronto-1975), him. 83. Lihatjuga Friedman, Legal Theory (London: Stem \& Soulimited, 1960), hlm. 456.

"Dahlan Thaib, Kedaulatan Rakyat, Negara Hukum dan Konstitusi, (Yogyakarta: Liberty, 2000), hlm. 45.

${ }_{12}$ Miriam Budiarjo, Dasar-Dasar IImu Politik, Cetak ketujuhbelas, (Jakarta: Gramedia Pustaka Utama, 1999), hlm. 99

${ }^{13}$ Sri Soemantri, op. cit., h/m. 45 
tidak lagi memenuhi syarat sebagai Presiden dan atau Wakil Presiden". ${ }^{\text {14 }}$

Pendapat Dewan Perwakilan Rakyat bahwa Presiden dan atau Wakil Presiden telah melakukan pelanggaran hukum tersebut ataupun telah tidak lagi memenuhi syarat sebagai Presiden dan atau Wakil Presiden adalah dalam rangka pelaksanaan fungsi pengawasan Dewan Perwakilan Rakyat. Dengan adanya fungsi pengawasan ini, apalagi ada ketentuan yang menegaskan Presiden tidak dapat membekukan dan atau membubarkan Dewan Perwakilan Rakyat's, maka perubahan ketiga UUD 1945 telah menempatkan DPR pada kedudukan yang kuat dalam sistem ketatanegaraan Indonesia mendatang.

Dari apa yang dikemukakan di atas, maka sekali lagi ingin ditegaskan bahwa dengan perubahan ketiga UUD 1945, maka dalam praktek ketatanegaraan yang akan datang MPR tidak lagi berposisi sebagai lembaga tertinggi negara tempat Presiden harus bertanggung jawab, juga MPR sebagai institusi tidak diperlukan lagi. Peran MPR berikutnya akan dilihat dari komposisi keanggotaan MPR yang terdiri dari anggota-anggota Dewan Perwakilan Rakyat (DPR), dan Dewan Perwakilan Daerah (DPD) yang dipilih melalui pemilihan umum. Sistem ini dikenal dengan nama sistem dua kamar atau sistem bikameral.

Perubahan struktur MPR ini tidak mesti membubarkan Negara Indonesia. Negara Kesatuan Republik Indonesia (yang di- desentralisasi) tetap dipertahankan, sistem ini bahkan diharapkan dapat mencegah ancaman disintegrasi bangsa, karena dengan adanya Dewan Perwakilan Daerah (DPD) yang pada hakekatnya adalah perwakilan dari daerah-daerah, maka DPD tentunya dapat menyuarakan kepentingan daerah dalan kerangka Negara Kesatuan Republik Indonesia.

Tidak dapat dipungkiri bahwa dalam rangka otonomi daerah, setiap daerah memiliki kepentingannya sendiri-sendiri yang harus diperjuangkan di pemerintahan pusat. Di sinilah fungsi dan peran Dewan Perwakilan Daerah (DPD) dalam sistem bikameral dalam praktek ketatanegaraan mendatang. ${ }^{16}$ Yang harus mendapat perhatian serius adalah betapapun kepentingan daerah tidak boleh diabaikan, namun dalam kehidupan berbangsa dan bernegara yang akan datang haruslah dijunjung tinggi komitmen menempatkan kepentingan nasional sebagai prioritas utama.

Lebih lanjut sebagai konsekuensi diterapkan sistem dua kamar ini, maka otomatis utusan golongan terhapus dalam komposisi MPR, sehingga tidak ada lagi kursi khusus buat TNI dan POLRI di MPR. Utusan golongan dan perwakilan TNI/POLRI dalam MPR ditiadakan tidak saja karena penerapan sistem perwakilan rakyat yang bikameral sebagaimana dikemukakan di atas, tetapi juga karena baik aspirasi Utusan Golongan maupun aspirasi TNI/POLRI dapat disalurkan melalui kedua lembaga legislatif tersebut.

Keberadaan Utusan Golongan dan

${ }^{14}$ Pasal 7A Perubahan Ketiga UUD 1945.

${ }^{15}$ Pasal 7B ayat 2 dan Pasal 7C Perubahan Ketiga UUD 1945.

${ }^{16}$ Lebih lanjut baca Pasa 22 D ayat 1, 2 dan 3 Perubahan Ketiga UUD 1945. 
Perwakilan TNI/POLRI diperlukan ataukah tidak seharusnya diukur dari jawaban atas pertanyaan berikut: a) Apakah aspirasi kelompok masyarakat yang dikelompokkan ke dalam Utusan Golongan dan aspirasi TNII POLRI tidak dapat disalurkan melalui mekanisme pemilihan umum, dan atau, b) Apakah kelompok masyarakat yang disebut Utusan Golongan dan TNIIPOLRI tidak lagi memiliki keberdayaan untuk mempengaruhi DPR dan DPD hasil pemilihan umum?

Siapapun atau partai politik apapun yang memegang kekuasaan pemerintahan dalam praktek ketaatnegaraan yang akan datang yakni pasca Pemilu 2004 niscaya akan mendengarkan aspirasi pegawai negeri sipil - dan pegawai negeri tentara dan kepolisian karena tidak saja mereka memiliki keberdayaan tetapi juga karena peran mereka sebagai aparat negara. Aspirasi sebagian kelompok masyarakat Utusan Golongan, karena jumlah anggotanyayang besar dan bila dapat diorganisasi sebagai pemilih yang sadar akan hak-hak politiknya, niscaya dapat diperjuangkan melalui mekanisme pemilihan umum, yaitu melalui, calon partai politik dan atau calon perseorangan, atau melalui pengaturan sistem rekruitmen calon dalam undang-undang pemilu yang akan datang sebagaimana diisyaratkan dalam Perubahan Ketiga UUD 1945, ${ }^{17}$ Aspirasi sebagian kelompok Utusan Golongan ini malahan dapat pula diperjuangkan sendiri melalui DPR dan DPD karena kelompok-kelompok ini memiliki keberdayaan.

Sehubungan dengan keberadaan dua kamar parlemen DPR dan DPD dalam sistem ketatanegaraan Indonesia mendatang, maka perlu ditentukan persamaan dan perbedaan di antarakeduanya. Kedua lembaga perwakilan ini mempunyai fungsi legislatif, fungsi pengawasan, dan fungsi anggaran. ${ }^{18}$ Masingmasing lembaga bersidang sedikitnya sekali dalam setahun. Keduanya dapat mengadakan rapat bersama yang dinamakan Majelis Permusyawaratan Rakyat (MPR). Kekuasaan perundang-undangan berada di tangan DPR dan DPD sesuai dengan struktur parlemen bikameral, karena keduanya sama-sama merupakan kamar lembaga legislatif (parlemen), maka setiap Undang-Undang menghendaki persetujuan kedua lembaga tersebut secara bersama-sama.

Apa kewenangan MPR dalam sistem bikameral tersebut? Apabila kita teliti perubahan ketiga UUD 1945, maka pembahasan dan . permberian persetujuan terhadap suatu Rancangan Undang-Undang (RUU) bukan merupakan kewenangan Majelis Permusyawaratan Rakyat sebagai sidang gabungan para anggota DPR dan para anggota DPD.

Perubahan RUU atau Rancangan UndangUndang adalah kewenangan DPR dan DPD sobagai lembaga yang mandiri, artinya pembahasan dan pemberian persetujuan/ penolakan terhadap suatu RUU dilakukan oleh sidang DPR dan Sidang DPD sendiri-sendiri. Majelis Permusyawaratan Rakyat (MPR) sebagai sidang gabungan DPR dan DPD dapat melakukan sidang bila diminta oleh DPR atau oleh DPD.

${ }^{17}$ Pasal 22 E Perubahan Ketiga UUD 1945 tentang Pemilihan Umum

${ }^{18}$ Pasal 22 E Perubahan Ketiga UUD 1945 tentarig Pemilihan Umum 
Berdasarkan perubahan ketiga UUD. 1945, Majelis Permusyawaratan Rakyat (MPR) berkewenangan: a) Menetapkan dan mengubah Undang-Undang Dasar, b) Melantik Presiden dan atau Wakil Presiden, dan c) Memberhentikan Presiden dan atau Wakil Presiden dalam masa jabatannya. ${ }^{19}$

Dari sudut pandang Hukum Tata Negara dengan substansi kewenangan seperti ini, maka Sidang Majelis Permusyawaratan Rakyat (MPR) dalam praktek ketatanegaraan yang akan datang dapat dikatakan sebagai relatif jarang dilakukan karena: a) Mengubah dan menetapkan Undang-Undang Dasar tidak akan dilakukan setiap tahun, dan b) Pemberhentian Presiden dan Wakil presiden hanya dilakukan bila ada usul dari Dewan Perwakilan Rakyat (DPR), itupun dengan terlebih dahulu mengajukan permintaan kepada Mahkamah Konstitusi untuk memeriksa, mengadili, dan memutus pendapat Dewan Perwakilan Rakyat bahwa Presiden dan atau Wakil Presiden telah melakukan pelanggaran hukum berupa pengkhianatan terhadap negara, korupsi, penyuapan, tindak pidana lainnya, atau perbuatan tercela dan atau pendapat bahwa Presiden dan atau Wakil Presiden tidak lagi memenuhi syarat sebagai Presiden dan atau Wakil Presiden. ${ }^{20}$

Melanjutkan apa yang dikemukakan di atas, maka meskipun kedudukan maupun fungsi DPR dan DPD adalah sama, tetapi perlu diadakan pembedaan dalam tugas pembahasan dan pengesahan rancangan undang-undaing.
Konstitusi baru Indonesia setelah perubahan menentukan bahwa pembedaan keduanya ditekankan pada bidang pengaturan yang menjadi urusan masing-masing. Misalnya menurut perubahan ketiga Undang-Undang Dasar 1945, DPD ditetapkan berwenang mengatur semua ketentuan yang berkenaan dengan Daerah: artinya DPD dapat mengajukan dan membahas Rancangan UndangUndang kepada DPR yang berkaitan dengan Otonomi Daerah, hubungan pusat dan daerah, pembentukan dan pemekaran serta penggabungan daerah, pengelolaan sumber daya alam dan sumber daya ekonomi lainnya serta yang berkaitan dengan perimbangan kekuasaan Pusat dan Daerah. Selain itu, DPD dapat memberikan pertimbangan kepada DPR atas Rancangan Undang-Undang. Anggaran Pendapatan dan Belanja Negara, serta Rancangan Undang-Undang yang berkaitan dengan pajak, pendidikan, dan agama. DPD diberikan kewenangan pengawasan atas pelaksanaan UndangUndang tersebut di atas. ${ }^{21}$

Persoalan mendasar dalam praktek ketatanegaraan yang akan datang adalah mengenai keanggotaan Dewan Perwakilan Daerah (DPD). Dalam Perubahan Ketiga UUD 1945 ditegaskan bahwa anggota DPD dari setiap propinsi jumlahnya sama dan jumlah anggota DPD itu tidak lebih dari sepertiga jumlah anggota DPR. ${ }^{22}$

Ketimpangan jumlah DPR dan DPD menjadi persoalan dalam konteks bikameral

\footnotetext{
19 Pasal 3 Perubahan Ketiga UUD 1945

${ }^{20}$ Paasl 7 Perubahan Ketiga UUD 1945

${ }^{21}$ Pasal 22 D ayat 1, 2, 3dan 3 Perubahan Ketiga UUD 1945.

${ }^{2}$ Pasal $22 \mathrm{C}$ ayat 2 Perubahan Ketiga UUD 1945
} 
pada masa yang akan datang. Masalahnya bagaimana menentukan quorum sidang MPR. Bila diterapkan ketentuan one man one vote (satu orang satu suara), berarti DPR'dapat mengabaikan kehadiran DPD: Artinya, Sidang MPR tidak memerlukan perssetujuan DPD karena jumlah DPR yang mayoritas.

Oleh karena itu, dalam praktek ketatanegaraan jangka panjang, perlu dipertimbangkan kehadiran konvensi ketatanegaraan agar anggota DPD ditambah dengan mempergunakan sistem bukan jumlahnya sama setiap propinsi, tetapi memilih satu anggota DPD per Kota/Kabupaten. Karenanya masalah keterwakilan daerah lewat DPD perlu memperoleh perbaikan dalam konteks ketatanegaraan Indonesia mendatang.

Namun penyempurnaannya tidak hanya diusahakan melalui jumlah keanggotaan DPD. Sebaiknya hal itu juga diatasi dengan perbaikan sistem kepartaian dan sistem pemilu, ${ }^{23}$ serta melalui berbagai peraturan perundàng-undangan yang menyangkut otonomi dan perimbangan keuangan pusat dan daerah serta undang-undang yang menyangkut hak asasi manusia.

Kehadiran sebuah Mahkamah Konstitusi yang berwenang memberi putusan atas pertentangan antar undang-undang akan membuat peraturan perundang-undangan, termasuk Undang-Undang Otonomi, Perimbangan Keuangan Pusat dan Daerah, dan sebagainya akan lebih efektif. ${ }^{24}$

Perbincangan atau diskursus tentang keterwakilan rakyat/daerah dalam lembaga'lembaga perwakilan sebagaimana dikemuka- kan di atas merupakan perbincangan tentang dan sekitar perwujudan demokrasi dulu, kini, dan yang akan datang dalam perpolitikan di Indonesia.

Dalam realitas Negara Kesatuan Republik Indonesia, keterwakilan merupakan legitimasi yang paling rasional sebagai. penghormatan yang dapat dijelaskan dengan satu pemahaman bahwa, pluralitas atau kemajemukan yang sangat mengkin terjadi dalam komunitas masyarakat Indonesia dapat terakomodai tanpa mengedepankan peran-peran anarkis dan dominasi atas satu kelompok oleh kelompok lain.

Dewasa ini pasca amandemen ketiga UUD 1945, banyak kalangan memperdebatkan keunggulan dan kekurangan relatif dari lembaga legislatif bikameral. Unikameralis berpendapat bahwa sistem dua kamar tidak lagi memenuhi kebutuhan keterwakilan karena anggota-anggota kedua kamar mewakili konstituen yang sama. Bikameralis berpendapat bahwa sitem dua kamar lebih mewakili banyak kepentingan yang saling tumpah tindih dari masyarakat yang majemuk. Terutamanya, keunggulan atau kekurangan dari dari sistem bikameral biasanya diperdebatkan dalam konteks keunggulan atau kekurangan sistem unikameral, dan kadangkala perdebatan juga menyentuh issue federalisme. Kedua pihak menekankan bahwa struktur yang mereka dukung itu lebih responsif terhadap rakyat dan tidak terlalu terpengaruh oleh kekuatan-kekuatan masyarakat yang dominan.

Namun demikian, tidak ada satu

\footnotetext{
${ }^{23}$ Baca lebih lanjut Pasal 22E Perubahan Ketiga UUD 1945 tentang Pemilihan Umum

${ }^{24}$ Pasal $24 \mathrm{C}$ ayat 1 Perubahan Ketiga UUD 1945
} 
sistempun, baik unikameral atau bikameral, bahkan federalis, dapat diterapkan secara universal, dan tipe sistem yang dipilih oleh satu masyarakat terutama tergantung pada keadaan politik, sosial, ekonomi, etnik, serta faktor-faktor lainnya.

Majelis Permusyawaratan Rakyat (MPR) melalui Sidang Tahunan MPR RI pada tanggal 9 November 2001 telah menetapkan sistem lembaga legislatif bikameral lewat perubahan UUD 1945. Prinsip yang mendasari ketetapan tersebut seperti telah ditunjukkan dari perdebatan yang mendahului penetapan tersebut baik di kalangan Tim Ahli Badan Pekerja MPR maupun di antara anggota Badan Pekerja MPR dan kalangan di luar MPR adalah usaha untuk mencapai "keterwakilan dan kemampuan responsif", dan juga keinginan untuk mewujudkan perimbangan kekuasaan antara Eksekutif dan Legislatif dalam sistem dan praktek ketatanegaraan mendatang.

Kendatipun hasil-hasil Sidang Tahunan MPR November 2001 belum menuntaskan sepenuhnya berbagai agenda politik, tetapi secara umum hasil amandemen ketiga pada bulan November 2001 itu sudah optimal, antara lain materi muatan pemilihan Presiden dan Wakil Presiden secara langsung oleh rakyat sudah ditetapkan dalam Perubahan Ketiga UUD 1945. Yang perlu dituntaskan pada Sidang Tahunan MPR yang akan datang dalam kaitannya dengan isu pemilihan Presiden dan Wakil Presiden secara langsung oleh rakyat adalah perselisihan terhadap kemungkinan adanya ronde kedua. Sebagian berpandangan bahwa sebaiknya ronde kedua dikembalikan lagi kepada rakyat, sedangkan sebagian yang lain berpendirian untuk menyerahkan saja kepada MPR.

Oleh karena perkembangan politik ketatanegaraan yang demikian, maka Pemilihan Umum tahun 2004 akan sangat berbeda dengan pemilu-pemilu sebelumnya. Jika pada pemilu-pemilu sebelumnya rakyat hanya memilih anggota DPR, DPRD l, dan DPRD II, maka pada Pemilu tahun 2004 juga akan memilih anggota Dewan Perwakilan Daerah (DPD), serta memilih Presiden dan Wakil Presiden. Jadi volume Pemilu tahun 2004 akan bertambah, sehingga bobot politiknya juga bertambah berat.

Berdasarkan gambaran yang dikemukakan di atas kendatipun banyak kendala yang dihadapi, maka amandemen keempat UUD 1945 harus dapat diselesaikan pada Sidang Tahunan MPR mendatang. Urgensii dari sudut hukum ketatanegaraan, dengan rampungnya proses amandemen keempat agar segera dapat menuntaskan berbagai RUU yang ada kaitannya dengan Pemilu 2004 seperti RUU tentang Susduk dan RUU Kepresidenan dan tentang Tata Cara Pemilihan Presiden Secara Langsung, misalnya kalau dalam pemilu putaran pertama tidak tercapai target setengah plus satur ${ }^{25}$ maka siapa yang akan memilih, diulang atau diserahkan kepada. MPR. Kegagalan dalam proses amandemen keempat akan bisa menimbulkan krisis ketatanegaraan dan krisis konstitusi, implikasinya Pemilu 2004 juga akan terancam batal.

Amandemen UUD 1945 yang ditugaskan kepadaPAHIBadan Pekerja MPR sebagaimana termuat dalam TAP MPR IXMPR/2000 dan juga

${ }^{25}$ Pasal 6 A ayat 3 dan 5 Perubahan Ketiga UUD 1945 
merupakan amanat reformasi, bukanlah pekerjaan sederhana, Karena itu, MPR harus berhati-hati dan dapat memposisikan dirinya sebagai negarawan bukan sebagai politisi dalam melakukan proses amandemen UUD 1945, agar amandemen tersebut dapat. memenuhi harapandan kehendak seluruh rakyat.

Amandemen UUD 1945 terkait dengan masa depan demokrasi di Indonesia, oleh karena itu Indonesia tidak boleh kehilangan kesempatan untuk melakukan amandemen tersebut demi terciptanya sistem ketatanegaraan dan sestem pemeerintahan yang demokratis.

Dengan konstitusi baru hasil amandemen bangsa Indonesia optimis terhadap masa depan demokrasi di Indonesia, Bangsa yang mampu bersikap optimis akan mempunyai energi mental untuk berkembang menjemput kemajuan dan perubahan, sebagaimana pesan Allah dalam Al Qur'an surat Ar Ra'ad ayat 11, "...Allah tidak akan mengubah nasib suatu bangsa kecuali apabila bangsa itu sendiri berusaha untuk mengubahnya."o

\section{Daftar Pustaka}

Budiarjo, Miriam, Dasar-dasar llmu Politik, Cetak ketujuhbelas, Jakarta: Gramedia Pustaka Utama, 1999.
Friedman, Legal Theory, London: Stern \& Soulimited.

M, Sri Soemantri, Prosedur dan Sistem Perubahan Konstitusi, Bandung: Penerbit Alumni, 1979.

National Democratic Intitute For International Affair (NDI), "Seri Penelitian Legislatif, Satu atau Dua Kamar?".

Thaib, Dahlan, Kedaulatan Rakyat, Negara Hukum dan konstitusi, Yogyakarta: Liberty, 2000.

Tim Peneliti Kerja Sama Puslitbang Kemasyarakatan dan KebudayaanLIPI, Reposisi Lembaga Tinggi Negara, Jakarta, Maret 2001.

Strong, C.F., Modern Political Constitution, London: ELBS Edition First Published, Sidgwick \& Jackson Limited, 1966.

Wheare, K.C., Modern Constitution, London: Oxford University Press, New YorkToronto-1975.

Perubahan Ketiga Undang-Undang Dasar Negara Republik Indonesia Tahun 1945

TAP MPR No. IX/MPR/2000

TAP MPR No. XI Tahun 2001

Kompas, 24 September 2001. 